\title{
LUDOWA BOJOWA KULTURA FIZYCZNA SŁOWIAN
}

\author{
DARIA ŁAWRYNOW \\ Uniwersytet Warszawski \\ Wydział Lingwistyki Stosowanej, Filologia Rosyjska \\ ul. Szturmowa 4, 02-678 Warszawa \\ e-mail: d.lawrynow@uw.edu.pl \\ ORCID: https://orcid.org/0000-0002-6064-353X \\ (nadesłano 17.08.2018; zaakceptowano 12.09.2018)
}

\section{Abstract \\ Slavic traditional martial arts}

This article discusses Slavic traditional martial arts such as hand-to-hand combat, team fight "stenka na stenku” („wall on wall”), traditional wrestling, folk games and ritual duels. The fighting traditions of the Cossacks, Russians, Ukrainians, Masovians and Kurpie are described, and their evolution and the history of development in Slavic societies analyzed. This paper examines the various functions of military culture: social, magical, entertaining and practical, as well as its role in the process of forming self-awareness and mentality of the groups described. The article is based on historical and folklore material.

\section{Key words}

Military culture, traditional martial arts, folk traditions, Cossacks, Mazovia.

\section{Резюме}

\section{Народная боевая физическая культура славян}

В данной статье рассмотрены проблемы славянской военной культуры на примере традиционных рукопашных состязаний, в том числе борьбы и кулачного 
боя, а также народных игрищ, забав и ритуальных состязаний. Статья освещает боевые традиции казачества, русских, украинцев, мазовшан и субэтнической группы курпы, анализируя их эволюцию, историю развития в славянских обществах. Данная работа рассматривает различные функции боевой культуры: социальные, магические, развлекательные и практические, а также их роль в процессе формирования самосознания и менталитета описываемых групп. Статья базирует на историческом и фольклорном материале.

\section{Ключевые слова}

Военная культура, традиционные боевые искусства, народные обряды, казачество, Мазовия.

Bojowa kultura fizyczna w środowisku i tradycji narodów słowiańskich mogła spełniać wiele ról i przybierać różne formy zależnie od okoliczności i miejscowych obyczajów. Obecnie bywa ona kojarzona raczej z wiejskimi bójkami, będącymi zwulgaryzowaną pozostałością dawnych rytualnych pojedynków i zawodów, organizowanych w ramach obchodów wybranych świąt kalendarzowych (Горбунов, 1997, s. 28-31; Perzanowski, 1995, s. 57-58; Мандзяк, 2006, s. 97-126). W charakterze najstarszych przykładów wśród badacze podają pojedynki na Rusi mające na celu upamiętnianie zmarłych wojów podczas tzw. tryzny - rodzaju stypy, której towarzyszyły uczty („strawa”), składanie ofiar oraz różnorakie gry - także nawiązujące do kultury militarnej (Яровой, 2014, s. 152-153; 184; Котляревский, 1868, s. 131; Снегирев, 1837, s. 25-27; Михайлина, 2007, s. 199; 234; Адамович, 2012, s. 143; Каляндрук, 2007, s. 239; 241-243]. Samo pojęcie „tryzny” najprawdopodobniej początkowo oznaczało 'zawody', 'pojedynek', a termin „tryzniszcze” - 'pole bitwy' (Снегирев, 1837, s. 25-27; Адамович, 2012, s. 143; Огієнко, 1965, s. 254-255). Spośród najstarszych rodzajów analizowanych gier i zawodów wymienia się pojedynki pięściarskie „jeden na jeden" lub ich zbiorową formę, w której naprzeciwko siebie stawały dwie uformowane w falange grupy (ukr. лава на лаву, ros. стенка на стенку). W opinii uczonych, ta ostatnia odzwierciedlała pieszy szyk bojowy, znany również w wojskowości Słowian, a sama formuła gry (bicie jedynie do „pierwszej krwi”, „ataki” frontalne bez zachodzenia od tyłu czy z boku, zakaz bicia leżącego, zakaz przechodzenia na stronę przeciwnika) miała za cel płynne wdrożenie męskich przedstawicieli społeczności w realia prawdziwych działań wojennych z towarzyszącą im dyscypliną oraz kodeksem honorowym (Горбунов, 1997, s. 43-46; 71-83). Podczas tego typu zmagań szczególnie ceniono nie tyle siłę fizyczną, ile przede wszystkim spryt, inicjatywę i technikę walki (Горбунов, 1997, s. 83-86; Терещенко, 1848, s. 81-83; Александров, 1999, s. 24-27; Железнов, 1910, s. 1116). Prócz pojedynków pięściarskich do archaicznych form zalicza się pochodzące z Azji zawody zapaśnicze, a niekiedy również walkę wręcz, toczoną w szyku konnym (Горбунов, 1997, s. 52). Zdarzały się również tzw. „boje plecami”, w których dwie stojące tyłem osoby zaplatały ręce i próbowały przerzucić przeciwnika przez pleсу na ziemię (Мандзяк, 2007, s. 53). Popularne były także organizowane w miesiącach 
zimowych zabawy w zdobywanie góry albo śnieżnych „twierdz”, „zamków” - tutaj jedna grupa pełniła rolę obrońców, a druga - atakujących (Яровой, 2014, s. 53-54). W przeciwieństwie do europejskich średniowiecznych turniejów rycerskich, na Rusi walczono zazwyczaj bez broni, wyjątek stanowiły piesze pojedynki na drewniane kije, mniej popularne aniżeli walka wręcz. W latach późniejszych, szczególnie wśród Kozaków, praktykowano również pojedynki z bronią białą.

Zdaniem Olega Matwiejewa, badającego bojową kulturę kubańskiej Kozaczyzny, podczas tradycyjnych ćwiczeń gimnastyczno-bojowych - tak samo jak w pracy fizycznej i w czasie operacji militarnych - nacisk kładziono na prostotę, precyzję, wytrwałość i odpowiednie gospodarowanie energią (Матвеев, 2002, online). Ćwiczenia, ale przede wszystkimi rozgrywanie sytuacji konfliktowych w warunkach zabawy i święta, pełniły rolę inicjacyjną dla młodych członków społeczeństwa, miały ich przygotować do dorosłego życia, które wymagało odpowiedzialności, odporności, hartu ducha i umiejętności podejmowania decyzji. Zapewne dlatego podczas zbiorowych walk pierwszą „falangę” stanowili najmłodsi, którzy z kolei ustępowali miejsca na „polu bitwy” młodzieży, a ta - dorosłym, kończącym zmagania i jednocześnie dającym młodszym przykład doświadczenia oraz techniki.

Wymienione wyżej gry i zabawy równie często organizowane bywały podczas świąt symbolizujących „moment przejścia”: zmian pór roku, cyklu agrarnego, a także podczas wesela czy pochówku. Stąd do wielu „konfrontacji” dochodziło także w miejscach "granicznych”: na miedzy, moście, skrzyżowaniach dróg, na górze albo świeżo usypanym kurhanie, pod którym złożono zmarłego (Яровой, 2014, s. 50-53, 141). Staroruskie bajki i byliny, opisujące pojedynki bohaterów z siłami demonicznymi, również toczą się na mostach, pod ziemią czy pod wodą albo w „czystym polu” (symboliczna granica świata ruskiego i azjatyckiego - „pogańskiego”).

Z obrzędowością wesela jako momentu przejścia do „innego domu, innego rodu” wiązano niektóre pieśni i zabawy, imitujące „odbijanie siłą” i „obronę” panny młodej. Mogą one stanowić pozostałość po znanych w Azji i na Kaukazie porwaniach żon (zwyczaj ten praktykowali również rosyjscy Kozacy) i zbrojnych pojedynkach kobiety z mężczyzną, które w przypadku wygranej mężczyzny kończyły się ślubem „antagonistów”. Podobne pojedynki, często uwieńczone ślubem, spotykamy w bylinach: staroruscy bohaterowie walczą tam wręcz, zbrojnie i konno z tzw. polanicami - bohaterskimi dziewicami, często obcego pochodzenia („ziemi lachowińskiej” albo „politewskiej” bądź córkami bliżej nieokreślonych królów odległych krain, a niekiedy królowymi „kobiecego carstwa”), szukającymi dla siebie przeciwników „w czystym polu” (Иликаев, 2015, s. 39-41; Ковпик, Калугина, 2008; Лельчук, [b.r.w.], s. 110-113; Колесов, 2000, s. 64; Воронин, 1966, s. 195; Алексеев, 2009). Przywodzi to na myśl dawne tradycje kazachskie, kiedy młoda dziewczyna wyznaczała kandydatowi na męża różnego rodzaju zadania, m.in. mierzyła się z nim podczas wyścigów konnych i w walce (Абдигалиева, Нукеджанов, 2010; Кузьменко, 2015).

W kontekście późniejszej obrzędowości weselnej można przytoczyć przykład z białoruskiej Homelszczyzny, gdzie bawiono się w „walkę” gości i „bojarów” o pannę młodą, kiedy goście śpiewali: 
Не наступай, Літва,

Бо будзе ў нас бітва,

Будом біці да воеваці,

Да свое Галонькі не оддаваці.

zaś „bojarzy” odpowiadali:

Вон, вон, казакі, з хаты,

Хочэ тут комусар стаці

Да з своею комусаркаю,

Да з кудравою да голоўкою.

(Новак, 2011, s. 124)

Podczas białoruskich obrzędów weselnych, kobiety-swaszki mogły również imitować działania bojowe, „organizując najazdy”, aby „odbić” pannę młodą, albo udawały straż przednią (Гамаш, 2008). Natomiast w ukraińskiej obrzędowości weselnej niezamężna kuzynka pana młodego niosła spleciony z kwiatów miecz albo szablę (Борисенко, 2016, s. 107-108; Мерлянова, 2012, s. 219).

Pojedynki miały również za zadanie zapewnienie pomyślności w gospodarstwie krew walczących symbolicznie „poiła” ziemię, aby ta dała obfity plon (Горбунов, 1997, s. 93-95; Яровой, 2014, s. 74). Magii agrarnej towarzyszyły też inne formy aktywności fizycznej o militarnym zabarwieniu, głównie kobiece tańce z mieczami wykonywane najprawdopodobniej ku czci bogini Łady - obecnie możemy je jeszcze obserwować w Chorwacji (Kolankiewicz, 1999, s. 283; Moszyński, 1967, s. 359). W Polsce wspominał o nich krakowski teolog Łukasz z Wielkiego Koźmina w swej Postylli (Mazur, 2014, s. 242-243). Tańce z bronią, tym razem męskie, są obecnie także szeroko rozpowszechnione na Kaukazie, Ukrainie i w Rosji. Ich korzenie sięgają społeczności, dla których działania zbrojne stanowiły podstawę bytu i swoisty styl życia, takich jak Kozacy, opryszkowie, zbójnicy - także ci z terenów polskich, których folklor odzwierciedlają tańce góralskie (Kubik, 1977, s. 50-52; Długołęcka, Pinkwart, online; Александров, 1999, s. 17-19; Мандзяк, 2006, s. 17-24; 150-151; Каляндрук, 2007, s. 177-186). Wśród karpackich opryszków umiejętność walki i tańca z bojowym toporkiem była niegdyś jednym z wyznaczników dojrzałości, swoistym testem na dorosłość dla młodego pokolenia, praktykowano również ćwiczenia w rzucie toporem do celu (Мандзяк, 2006, s. 150-153).

Jak można stwierdzić na przykładzie powyższych danych faktograficznych oraz analizy źródeł, bojowa kultura fizyczna miała wiele aspektów: sprzyjała działaniom magicznym, odzwierciedlała wierzenia i przesądy ludu, podkreślała znaczenie wydarzeń przełomowych dla społeczności. Z drugiej strony pełniła ona rolę działań socjalizujących, szczególnie wśród społeczności, dla których wojna stanowiła zajęcie podstawowe, przyrodzony „fach”. Nie dziwi zatem fakt, że zmilitaryzowane gry i zabawy najdłużej przetrwały w takich społecznościach, jak na przykład u rosyjskich Kozaków. Ulubioną rozrywką dzieci i młodzieży, niekiedy również dziewcząt, były staroruskie „kułaczki”, czyli wspomniane wyżej pojedynki pięściarskie, ale przede wszystkim odgrywanie bitew $\mathrm{z}$,niewiernymi”: Turkami, Tatarami, ludami kaukaskimi - imitowały one nie tylko samą taktykę walki, ale też branie jeńców czy wybory dowódcy - atamana (Железнов, 1910, s. 11-16; Щербина, online; Александров, 1999, s. 16-17; 
Каляндрук, 2007, s. 253-256; Мандзяк, 2007, s. 39-43). Stanowiły typowe odgrywanie „dorosłego życia”. Innymi popularnymi zabawami były zajęcia rozwijające spryt, wytrzymałość, siłę i technikę: przeciąganie liny bądź kija, skoki przez kij i szablę, siłowanie się na ręce oraz nogi - to ostatnie w pozycji na plecach (tzw. „walka cygańska”), wzajemne przydeptywania nogami - wyrabiające czujność, refleks. Inne miały za cel wyrabiać wytrwałość i odporność na ból czy chłód (Александров, 1999, s. 16-17; Адамович, 2012, s. 6; 20; 143-150). Dzieci odtwarzały też musztrę i taktykę kawalerską. Młodzież ćwiczyła techniki użycia broni białej przecinając w powietrzu podrzucane źdźbła bądź ćwicząc cięcia słomianych figur w pełnym galopie. Niekiedy praktykowano również techniki uczące odporności na ciosy (wykonywanie na zmianę uderzeń w poszczególne części ciała) czy umiejętności uwolnienia się od dźwigni (Мандзяк, 2006, s. 91-92; Мандзяк, 2007, s. 51-52). Dla młodzieży organizowano zawody, w których sprawdzano umiejętności strzelania i cięć szablą czy uderzeń piką w galopie, podnoszenia przedmiotów z ziemi konno (Яровой, 2014, s. 17-18).

Rodzice dzieci kozackich od najmłodszych lat starali się wdrożyć potomków do realiów wojennych, tworząc wokół nich swoisty zmilitaryzowany mikroświat: tuż po narodzinach chłopca najbliższa rodzina przynosiła mu w prezencie naboje lub strzały, a wraz z pojawieniem się u niego pierwszego zęba, ojciec bądź chrzestny sadzał go na konia, zaś do boku przypinał szablę, i obserwował, czy potomek zachowuje się „po kozacku”, tzn. czy trzyma się w siodle. Również w kozackich kołysankach pojawiają się atrybuty wojenne, swoisty kult rzemiosła militarnego (Багизбаева, 1977, s. 97-98):

Богатырь ты будешь с виду

и казак душой (...)

И отец твой, храбрый воин,

закален в бою.

W wojskach kozackich nawet mundur miał znaczenie kultowe i symboliczne, a musztra i ćwiczenia wojenne urastały do rangi miejscowej kultury ludowej. Sam program dziewiętnastowiecznego kozackiego wychowania fizycznego został ustrukturyzowany i opierał się nie tylko na nauce musztry, maszerowania, strzelania, jazdy konnej czy opanowaniu wielkiej ilości technik cięć szablą i ataków piką - zarówno w szyku pieszym, jak i konnym - ale także na gimnastyce, tańcach, dżygitówce, czyli popisach akrobatycznych, wykonywanych podczas jazdy konnej, oraz nauce pieśni - te ostatnie tradycyjnie opierały się na tempie marszowym, miały za zadanie wprowadzenie Kozaka w stan swoistego transu bojowego, służyły hartowaniu przysłowiowego ducha bojowego (Медведев, 1993; Козлов, 2003; Александров, online; Фігурний, 2004, s. 70; Яровой, 2014, s. 178; Наумов, 2010, s. 242-243; Бондарь, online; Кашкаров, 2015, s. 4-6; 20; 82).

O ile co najmniej od XVIII wieku wśród rosyjskich i ukraińskich mas ludowych przytoczone przykłady kultury fizycznej przybrały formę symboliczną, o tyle wśród Kozaków pełniły one rolę praktyczną - uczyły „fachu”, podtrzymywały ciągłość pokoleń. W związku z tym wielu badaczy mówi wręcz o wyewoluowaniu specyficznych ukraińskich, rosyjskich, białoruskich i kozackich systemów bojowych (np. „Spas”, „Krywicz”, „Liubki”) (Медведев, 1993; Пилат, 1999; Шевцов, 2010; Адамович, 2012; Бондаренко, Пустовойтов, Задунайский, 2010; Туманов, Еганов, Неретина, 
Князев, Туманов, Сапегин, 1999; Каляндрук, 2007, s. 55-70). Co ciekawe, na Ukrainie, gdzie Kozaczyzna jako zmilitaryzowana społeczność o specyficznych cechach etnicznych nie przetrwała tak długo jak w Rosji czy Kazachstanie, same tradycje bojowej kultury fizycznej dotrwały nawet do XX wieku - szczególnie jako młodzieżowe gry zręcznościowe, nawiązujące do tradycji kozackich, na przykład gra w Kozaków i Tatarów, przypominająca znaną zabawę w podchody, zabawy w „wojnę”, zręcznościowe zabawy łączące elementy tańca i walki (tańce z szablami czy kijami, wzajemne przeskakiwanie przez siebie z imitowaniem „kopniaków” itp.) (Мандзяк, 2007, s. 34-35).

Wśród ludności cywilnej popularność dorocznych pojedynków można byłoby tłumaczyć ich rolą w rozładowywaniu negatywnych emocji, niwelowaniu napięć psychicznych nagromadzonych przez cały rok. Szczególny rodzaj kultury fizycznej, sięgający korzeniami dawnej Rusi, a w sferze kultury - przynależny ludowej kulturze śmiechu - stanowiły niektóre pokazy tzw. skomorochów, czyli wędrownych artystów, oparte na pojedynkach człowieka ze zwierzęciem, najczęściej niedźwiedziem. Później, w okresie nowożytnym, wędrowcom towarzyszyli zawodowi „mocarze”, czyli siłacze, których zadaniem było toczenie publicznych pojedynków ze wszystkimi napotkanymi śmiałkami. Dla wielu z czasem stało się to nawet źródłem utrzymania, gdyż za każdą wygraną walkę otrzymywali stosowną zapłatę, a w XIX wieku wielu z nich zasiliło również trupy cyrkowe (Горбунов, 1997, s. 68-69).

Zawody i pokazowe pojedynki, jak można stwierdzić na podstawie źródeł folklorystycznych (byliny, epickie pieśni o tematyce historycznej), stanowiły często urozmaicenie wielu świąt na dworze carskim czy książęcym, a dla samych walczących stanowiły szansę na uzyskanie dodatkowych monarszych łask. Jeden z takich pojedynków, wraz z opisem technik walki, barwnie ukazuje Pieśń o Kostriuku (Песня о Кострюке), której akcja toczy się podczas uczty weselnej cara Iwana IV:

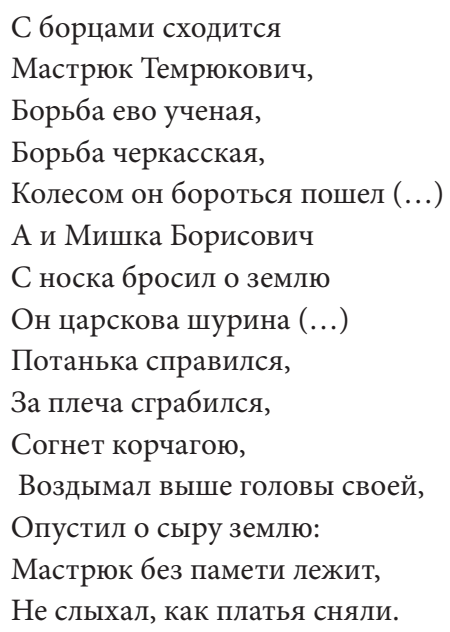

(Данилов, 1977)

W bylinach równie często pojawia się postać bohatera, a niekiedy też bohaterki, dla których sposobem na życie było wędrowanie po świecie w poszukiwaniu okazji do pojedynków. Wszyscy oni funkcjonują na granicy światów, są postaciami niejednoznacznymi: równocześnie toczą boje z wrogami „Świętej Rusi” oraz potrafią szantażo- 
wać monarszy dwór w Kijowie, domagając się „godnego przeciwnika”. Wykorzystują fachowe bojowe umiejętności do walki z ludźmi i z przedstawicielami świata nadprzyrodzonego, takimi jak demony, Baba Jaga, smoki. W jednej z bylin pochodzącej z terenów dzisiejszego obwodu wołgogradzkiego, przedstawiona została moralizatorska historia o trzystu dumnych herosach marzących, aby ich brańcami zostali „car świętoruski”, a nawet Chrystus. Ten ostatni zsyła z nieba bohaterkę-, polanicę”, która pokonuje wspomnianych śmiałków w pojedynku (Гypa, 1965). Tematyka twórczości ludowej dodatkowo potwierdza podwójną rolę bojowej kultury fizycznej: magiczną i praktyczną. Warto byłoby zwrócić uwagę, że pomimo wielkiej popularności walk, szczególnie tych na pięści, cerkiew potępiała je jako przejaw pogaństwa. Już w XIII wieku podczas soboru metropolita Cyryl nakazał ekskomunikować osoby uczestniczące w „bojach”. $\mathrm{Z}$ drugiej strony w pojedynkach chętnie brali udział nawet przedstawiciele elit. Jedna z najstarszych wzmianek piśmienniczych z XIII wieku mówi o pięściarskim pojedynku kniazia kijowskiego z pskowskim (Терещенко, 1848, s. 81-83; Грунтовский, 2002, s. 319).

Poza rytualno-obrzędową otoczką zmagania zbrojne stanowiły również element kultury prawnej dawnych Słowian. Pojedynek mógł stanowić element wstępny przed właściwym bojem wrażych armii, któremu towarzyszył na ogół określony schemat, przejmowany następnie przez gry: zwyczajowe, prześmiewcze wyzwiska pod adresem przeciwnika (niekiedy $\mathrm{w}$ formie rymowanej), wystąpienie $\mathrm{z}$ szeregu jednego ze śmiałków, który prowokował stronę przeciwną do wystawienia swojego ochotnika, oraz samo przystąpienie do pojedynku. Niekiedy właśnie ów pojedynek rozstrzygał o wyniku boju i dalszych działaniach dyplomatycznych obu stron (Афанасьев, 1995; Долгов, 2014). Stąd zresztą wywodzi się swego rodzaju cywilne odbicie ówczesnej kultury zbrojnej: instytut pojedynku sądowego. Był on rozpowszechniony wśród plemion germańskich (wspominają o nim Leges Barbarorum), a także w średniowiecznej Europie - miał przy tym religijne tło. Na Rusi funkcjonowało natomiast tzw. „pole”, które również miało moc rozstrzygania sporów sądowych, a najważniejszym warunkiem pojedynku była zasada równości antagonistów - z tego powodu kobiety, mnisi, małoletni, starzy czy chorzy mieli możliwość wystawienia najemnika (Афанасьев, 1995; Долгов, 2014; Olbrychski, 2013). Niedopuszczalne też było, aby przedstawiciel zbrojnej warstwy społecznej wyzywał na pojedynek „cywila”, jednakże dopuszczano sytuację odwrotną. Co ciekawe, sądziły się między sobą dwie kobiety, to również one musiały osobiście przystąpić do walki. Stosowne akty prawne precyzowały zasady i okoliczności, dopuszczalne rodzaje broni. Samo użycie broni, a także częsta walka w pełnym rynsztunku, odróżniały ów rodzaj pojedynku od innych form omawianej bojowej aktywności fizycznej. Pierwsze wzmianki o „polu” na Rusi pochodzą już z X wieku. Źródła arabskie i bizantyjskie wspominają o pojedynkach na miecze, kończących się częstokroć śmiercią jednej ze stron (Долгов, 2014). Natomiast najstarsze ruskie źródła podejmujące ten temat odnoszą się dopiero do XIII i XIV wieku. Sam pojedynek sądowy, jak na akt oficjalny przystało, był bardzo sformalizowany, towarzyszył mu ustanowiony prawnie schemat, a „pole” musiało odbywać się w asyście urzędników państwowych (Афанасьев, 1995; Долгов, 2014).

Instytucja pojedynku sądowego istniała również w dawnej Polsce, wspomina o niej Najstarszy zwód prawa polskiego, datowany na końcówkę XIII bądź początek XIV wie- 
ku. Do tego typu rozstrzygnięcia dopuszczani byli przedstawiciele wszystkich stanów, zatem walczyć mogli nawet chłopi z rycerzami, jednak w takim przypadku, aby zagwarantować stronom sprawiedliwe warunki, zamiast na miecze - walczono kijami (Olbrychski, 2013). Akty prawne Rzeczypospolitej, podobnie jak na Rusi, również regulowały zasady i sposoby przeprowadzania pojedynków. Nie zmienia to faktu, że w świadomości mieszkańców Rzeczypospolitej Obojga Narodów zbrojne rozstrzygnięcia sporów postrzegane były jako coś naturalnego, zwyczajowego. Szczególnym zamiłowaniem do zwady i bójek odznaczali się, wedle źródeł, mieszkańcy Mazowsza, przy czym zazwyczaj podkreślano równocześnie ich umiejętności wojskowe (Smoleński, 1908, s. 62-68; Wójcicki, 1869, s. 44-48). Nawiązuje do tego popularne w XV wieku przysłowie o czterech najlepszych atrybutach wojny, wśród których znalazł się też „chłop Mazurek”. Skłonność do zwady połączona z ubóstwem bywała również obiektem kpin ze strony „Koroniarzy”, czyli mieszkańców innych rejonów Rzeczypospolitej, wierszowano m.in., że Mazur ma ostrą szabelkę, „wyszczerbioną w bojach z chłopami w karczmie” (Smoleński, 1908, s. 137). Warto w tym miejscu oddać głos księciu Jabłonowskiemu, który powtarza jedną z opinii o ówczesnych Mazurach: „Co zaś do żołnierstwa, mają serce i ran i śmierci lekceważenie, bo sami się między sobą jak psy biją. Zły jarmark, kiedy tylko pięciu zabiją" (Wójcicki, 1869, s. 44). Jak wynika ze źródeł, mieszkańcy Mazowsza nigdy nie rozstawali się z bronią - nie tylko w życiu codziennym, ale także podczas odpustów, a nawet nabożeństw. W aktach prawnych książąt mazowieckich jak bumerang powraca temat kar i zakazów związanych z nadmiernym „uzbrojeniem” szlachty oraz chłopów na jarmarkach i w kościołach. Do ulubionych typów broni Mazurów należały: sękate kije, obuchy, szable, rusznice oraz nadziaki (Smoleński 1908, s. 64-66; Wójcicki 1869, s. 46; Perzanowski, 1995, s. 69). Umiejętność strzelania była szczególnie ceniona na Kurpiach, gdzie strzelba stanowiła jedną z podstaw bytu. Stąd zwyczaj dorocznych zawodów strzeleckich dla dzieci i młodzieży, a także swoisty „trening” w domu rodzinnym: ojciec, aby wpoić synom, że pożywienie należy zdobywać własnymi siłami, wieszał na drzewie kawałek jedzenia, a potomkowie musieli go strącić za pomocą strzału, aby zasłużyć na śniadanie. Młodzież uczestniczyła również w polowaniach, których zwieńczeniem było porównanie zdobyczy wszystkich męskich członków rodziny (Chętnik, 1924). Broń palna miała dla Kurpiów znaczenie niemal kultowe, jedna z pieśni okresu zaborów opowiada nawet o tym, jak mieszkańcy Puszczy opłakiwali skonfiskowane im przez zaborcę strzelby.

Wypadałoby podkreślić, że Mazurowie, w przeciwieństwie do Rusinów, nie posiadali uschematyzowanego systemu kultury bojowej o silnym zrytualizowaniu. Ich aktywność fizyczna kształtowała się raczej spontanicznie, a „hartowała” w sąsiedzkich zwadach czy karczemnych awanturach. Podobno nierzadkie były nawet bójki pomiędzy rodzicami a potomkami, krewkością odznaczały się również kobiety (Smoleński, 1908, s. 62-68).

Zjawisko zbójnictwa, tak chętnie kojarzone z terenami górskimi, na Mazowszu było szczególnie rozpowszechnione jeszcze zanim kroniki utrwaliły postaci i czyny pogranicznych „harnasiów”. Wśród Mazurów najczęściej dochodziło do aktów typowego łupiestwa plebanii i przybytków kościelnych, a niekiedy sąsiednich majątków - dokonywała tego miejscowa uboga szlachta (Smoleński, 1908, s. 63-64; Syska, 1955, s. 67). Należy zaznaczyć, że w przeciwieństwie do ludów góralskich, Mazurowie nie 
stworzyli własnej kultury militarnej. Górskie pogranicze polsko-ukraińsko-słowackie wykształciło swój własny fenomen kultury zbójnickiej z towarzyszącą mu obrzędowością i kulturą fizyczną. Postać „harnasia” w świadomości społecznej kojarzona była nie tylko ze swoistą sprawiedliwością ludową, ale też z ucieleśnieniem pewnych cech i umiejętności. Jak trafnie już w XIX wieku zauważył Seweryn Goszczyński, dla górala samo „zbójowanie” było „rodzajem rycerskiej szkoły”, a zbójnicy mieli się charakteryzować „niepospolitą siłą, zadziwiającą zręcznością w rzucaniu toporkiem, szybkością w biegu, gibkością w tańcu” (Kroh, 1971, s. 80-81). Zbójnicy, podobnie jak Kurpie czy Kozacy, otaczali osobistą broń swoistym kultem - była ona gwarantem swobody i nieodłącznym elementem życia codziennego. Na broń przysięgano też wierność „bractwu zbójnickiemu" (Сенько, 2006). Do ulubionych typów broni zbójników należały toporki, broń palna, rohatyna, nóż (tzw. czełepyk). Wśród karpackich górali prawo noszenia bałty (bojowego topora) było równoznaczne z uznaniem młodzieńca za pełnoprawnego członka społeczności - na owo prawo należało sobie zasłużyć umiejętnym posługiwaniem się wspomnianą bronią. Swoistym treningiem dla młodzieży były tańce, w trakcie których uczono się cięć i uderzeń toporem (Мандзяк, 2006, s. 150-151). Jak wynika z dziewiętnastowiecznych wspomnień Kleina i Blumenfelda, zbójnicy mieli nawet w zwyczaju tańce z nabitymi strzelbami (Eljasz-Radzikowski, 1897, s. 25-26). Istniała również piosenka ludowa, wychwalająca broń (raczej: prezentująca zalety broni) karpackich „opryszków”:

Як топірцем замахаю - ні німця, ні ляшка.
Та як стрілю з револьвера, із того нового,
Ой із того, що м зробив - із дерев’яного.
Штири ножі і револьвер за поясом ношу,
Дають мені пани гроші, коли в них попрошу

(Луців, 2014, s. 11)

Umiejętności zbójników do tego stopnia imponowały ludności, że wśród Rusinów krążyły legendy o „zaczarowanej broni” karpackich opryszków oraz różnorakich znanych im „sztuczkach”, np. opryszek Szuhaj był w stanie strzałem zapalić fajkę jednemu z żandarmów, a Metacz potrafił za pomocą noża lub zwykłego kamienia zabić hajduka - członka straży bocznej (Сенько, 2006; Луців, 2014, s. 10). Dla porównania, wśród Polaków krążyły liczne opowieści o kunszcie strzeleckim Kurpiów: jeden spośród nich miał jakoby w obecności króla Zygmunta Augusta „wypisać” strzałami na drzewie jego inicjały (Braun, online).

Zarówno na Rusi, jak i na Mazowszu świętom i odpustom towarzyszyły bijatyki. Analogicznie też funkcjonowały na tych terenach grupy rówieśnicze, tzw. „kawalerka”, które rywalizowały pomiędzy sobą, tworząc swoistą subkulturę młodzieży wiejskiej. Toczone przez nie bójki stanowiły jeden z elementów wiejskiej kultury świątecznej, stąd też do zadań „kawalerki” należało w pierwszym rzędzie zorganizowanie „muzyki”: wynajęcie pomieszczenia na zabawę taneczną i opłacenie grajków (Perzanowski, 1995, s. 56-57). Tego typu „oprawa” nie była niczym niezwykłym, zważywszy, że wedle źródeł, taniec, hulanka, pijatyki i walka stanowiły ulubione, główne źródła rozrywki dawnych Mazowszan. Jak głosiła jedna z pieśni ludowych: „Wtedy Mazur wesół żyje, kej tańcuje i kej bije” (Smoleński, 1908, s. 144). 
Co ciekawe, sama „bitka” często była tylko jednym z elementów zabawy, swoistym przerywnikiem pomiędzy tańcami. Konflikty fizyczne, akty przemocy towarzyszące zabawom paradoksalnie pełniły rolę socjalizującą młodzież: miały udowodnić, że kawalerowie nie przynależą już do świata dziecięcego, iż są oni w stanie „rządzić” w okolicy dzięki okazaniu swej przewagi nad przedstawicielami „kawalerki” sąsiedniej wsi czy okolicy. Bójki traktowano głównie jako rodzaj „sportu”, źródło adrenaliny, ale także pretekst do udowodnienia własnego prestiżu. Z czasem niektóre „draki” przybrały bardziej przestępcze formy: wytworzyły się specyficzne grupy bandyckie, których głównym zajęciem było wędrowanie po okolicznych weselach w celu ich „rozbicia”, prowokowanie konfliktów i rozbojów (Perzanowski, 1995, s. 57-58). Co ciekawe, w niektórych wsiach umiejętności bojowe były dziedziczne, a tzw. „herszci kawalerki”, „bijacy” mieli za zadanie wyszkolenie młodszych, wprowadzenie ich w realia, aby mogli „bronić honoru” wsi podczas przyszłych konfliktów. Bójki spełniały tym samym funkcję konsolidacyjną dla grupy rówieśniczej określonej wsi czy okolicy. Same bijatyki były toczone wręcz, ale mogła im towarzyszyć również typowa broń: noże, sprężyny, lagi, kamienie czy osławione sztachety. Młodzieńcy często demonstracyjnie obnosili się z „rynsztunkiem” - dla podkreślenia prestiżu i udowodnienia własnej dorosłości. Warto byłoby wspomnieć, że mazowieckie działania bojowe często miewały bardziej prymitywny i brutalny charakter: mimo iż nierzadko towarzyszyły im pojęcia obrony honoru, czci, to znane źródła nie wspominają o jakimś ustalonym, zwyczajowym zbiorze zasad, regulujących przebieg pojedynków. Nie można zatem mówić o istnieniu miejscowego systemu kultury fizycznej. Jednakże utrwaliły się pewne schematy, symbolizujące początek konfliktu. Schematyczną zaczepkę, swoiste zaproszenie do konfrontacji, stanowiło niegdyś wyrażenie „Pęknij no mię". Często gaszono światła w pomieszczeniu albo prowokacyjnie coś niszczono, aby „dać sygnał” do konfliktu (Wójcicki, 1869, s. 44; Perzanowski, 1995, s. 61).

Pomimo zawadiackiego usposobienia Mazowszan i Kurpiów oraz umiejętności zbrojnych, udowodnionych podczas wielu powstań czy wojen dawnej Polski (np. udział mieszkańców puszcz kurpiowskich we wszystkich polskich powstaniach okresu zaborów czy ich czynny udział w walkach ze Szwedami), nie wytworzyły się tu zalążki miejscowego systemu bojowego czy też unikalnej kultury fizycznej. Z drugiej strony pewne zalążki specyficznej kultury militarnej wytworzyło górskie pogranicze, związane z fenomenem społecznym zbójnictwa.

Sama tradycja pojedynków na Rusi i w Rzeczypospolitej posiada zapewne wspólne źródła, jednakże rozwijała się w odmienny sposób. Wśród Kozaków rosyjskich i ukraińskich tradycje bojowe utrzymywały się najdłużej, gdyż sam charakter tych społeczności kształtował się na zasadach demokracji militarnej, a ich tożsamość hartowała się w poczuciu ciągłego zagrożenia ze strony wszechotaczających „obcych”. W innych regionach Rosji, Ukrainy czy Białorusi ludowa bojowa kultura fizyczna przekształciła się w zabawę, ciekawostkę folklorystyczną - z czasem tracąc swe praktyczne i rytualne znaczenie. Niektóre jej elementy zlały się przy tym z kulturą rycersko-szlachecką. W Polsce działo się podobnie, przekazywane zaś z pokolenia na pokolenie umiejętności szybko utraciły „metafizyczną” otoczkę, spełniając funkcje czysto praktyczne: podczas wojen oraz rozstrzygania sporów. 


\section{Bibliografia}

Braun, K. (b.r.w.). Kurp Zbrojny - powstanie regionalnego etnomitu. Online: http://www.historia.kurpie.com.pl/kurp_zbrojny/ (15.08.2018).

Chętnik, A. (1924). Kurpie. (Biblioteczka Geograficzna „Orbis”, seria 3, t.4). Kraków-Dębniki: Nakł. Księgarni Geograficznej „Orbis”.

Ciupazki se rubaty. Online: http://www.zbojnickiszlak.pl/index.php?menu=c\&id_menu=99 (15.08.2018).

Długołęcka, L., Pinkwart, M. (b.r.w.). Muzyka i Tatry: taniec góralski. Online: www.pinkwart.pl/muzyka_i_tatry/spis_tresci.htm (13.08.2018).

Eljasz-Radzikowski, S. (1897). Podhalanie i Tatry na początku XIX wieku. Lwów: nakładem Towarzystwa Ludoznawczego.

Kolankiewicz, L. (1999). Dziady: teatr Święta Zmarłych. Gdańsk: Słowo/ Obraz/ Terytoria.

Kubik, J. (red.) (1977). Z zagadnień folkloru muzycznego na Śląsku Cieszyńskim. (Prace Naukowe Uniwersytetu Śląskiego nr 141). Katowice: Wydawnictwo Uniwersytetu Śląskiego.

Kroh, A. (1971). Zbójnik podhalański w kulturze polskiej. Polska Sztuka Ludowa, nr 2, s. 79-98.

Mazur, M. (2014). Wybrane zagadnienia z chrystianizacji krajów Europy środkowo-wschodniej i północnej w IX-XI wieku. Napięcia społeczne, przemoc i synkretyzm religijny. Vade Nobiscum, t. 11, Kacprzyk, E., Gawryszcza, M. (red.). Łódź: Uniwersytet Łódzki, s. 237-246.

Moszyński, K. (1967). Kultura ludowa Słowian (T. 1: Kultura materialna; T. 2: Kultura duchowa). Wyd. 2. Warszawa: Książka i Wiedza.

Olbrychski, A. (2013). Pojedynki sądowe w Polsce średniowiecznej. Online: www.wolnemedia.net/ pojedynki-sadowe-w-polsce-sredniowiecznej/ (13.08.2018).

Perzanowski, A. (1995). Bzij, zabzij, ja honorem ręce... Bójka wiejska - walka i rytuał. Polska Sztuka Ludowa - Konteksty, t. 49, z. 1, s. 55-63.

Smoleński, W. (1908). Szkice z dziejów szlachty mazowieckiej. Kraków: Druk. W. L. Anczyca i Spółki.

Syska, H. (1955). Obleciałem Kurpie-Gocie. Warszawa: Ludowa Spółdzielnia Wydawnicza.

Wójcicki, K. W. (1869). Szkice historyczne i z domowego życia niedawno ubiegłej przeszłości. Kraków: Drukarnia Uniwersytetu Jagiellońskiego.

Абдигалиева, Г. К., Нукеджанов А. (2010). Традиции и обычаи в казахской культуре. Вестник КазНУ, № 2 (35), s. 167-171.

Адамович, Г. Э. (2012). «Кривич». Рукопашный бой: система славянских единоборств. Минск: Букмастер.

Александров, С. Г. (1999). Отражение традииий физической подготовки в устном народном творчестве кубанского казачества. Армавир. Online: http://www.cossackdom.com/calture/ alexandrov_podgotovka.htm (13.08.2018).

Алексеев, С. В. (2009). Славянская Европа V-VIII веков. Москва: Вече.

Афанасьев, А. Н. (1995). Русское поле или суд божий. W: Поэтические воззрения славян на природу. Москва: Современный писатель.

Багизбаева, М. М. (1977). Фольклор семиреченских казаков. Ч. 1. Алма-Ата: Мектеп.

Бондаренко, В. В., Пустовойтов, В. Н., Задунайский, В. В. (2010). Казачий рукопашный бой. (Серия Бойцовский клуб). Москва: Астрель СПб.

Борисенко, В. К. (2016). Сімейна обрядовість українців XX - початку ХХІ століття. Київ: Борисенко, В. К. (2016). Сімейна обрядовість українців XX - початку ХХІ століття. Київ: Видавництво ІМФЕ.

Воронин, Н. Н. (1966). Культура древней Руси: посвящается 40-летию научной деятельности Николая Николаевича-Воронина. Москва: Наука. 
Гамаш, Д. Поліські амазонки чоловіків тримали за невільників. Газета по-украӥнськи. 19.06.2008. Online: www.gazeta.ua/articles/history-newspaper/_poliski-amazonki-cholovikivtrimali-za-nevilnikiv/234629 (13.08.2018).

Горбунов, Б. В. (1997). Традиционные рукопашные состязания в народной культуре восточных славян XIX - начала XX вв. Москва: Координационно-методический центр прикладной этнографии Института этнологии и антрополии РАН.

Грунтовский, А. В. (2002). Потехи страшные и смешные: книга о фольклорном театре, скоморохах, ряженых и кулачных боях. Санкт- Петербург: «Русская земля».

Гура, В. В. (сост.) (1965). Народное устно-поэтическое творчество Вологодского края: сказки, песни, частушки: в 2-х т. Архангельск: Северо-Западное книжное издательство.

Данилов, К. (1977). Древние российские стихотворения, собранные Киршею Даниловым. Москва: Наука.

Долгов, В. В. (2014). Поединки в древнерусской воинской культуре. Военно-исторический журнал, № 6, с. 57-60.

Железнов, И. И. (1910). Уральиь:: очерки быта уральских казаков. Санкт-Петербург: Общественная польза.

Иликаев, А. (2015). Русские былины и сказания. (Серия Мифы и легенды народов мира). Москва: Эксмо.

Каляндрук, Т. (2007). Таємниці бойових мистецтв Украӥни. Львів: Піраміда.

Кашкаров, А. П. (2015). Казаки: традиции, обычаи, культура (краткое руководство настоящего казака). Ростов-на-Дону: Феникс.

Ковпик, В., Калугина, А. (2008). Былины: исторические песни. Баллады. Москва: Эксмо.

Козлов, В. В. (2003). Физическое воспитание в казачьих юнкерских и военных училищах императорской России (1867-1917 гг.). Военно-исторический архив, № 11 (47).

Колесов, В. В. (2000). Древняя Русь: наследие в слове: мир человека. (Серия Филология и культура). Санкт-Петербург: Филологический факультет Санкт-Петербургского государственного университета.

Котляревский, А. (1868). О погребальных обычаях языческих славян. Москва: Типографія К. А. Попова.

Кузьменко, И. (2015). Казахская женщина - хранительница традиций и семейного очага. 19.02.2015. Online: https://e-history.kz/ru/publications/view/971 (13.08.2018).

Лельчук, А. М. (b.r.w.). Честь-хвала богатырская. Русские народные былины киевского цикла в переложении Алексея Лельчука. Тусские былины. Online: http://www.byliny.ru/a_lelchuk/ chest-hvala (13.08.2018).

Луців, Є. (2014). Бойове мистецтво гуиулів. Тернопіль: Мандрівець.

Мандзяк, О. (2006). Бойові традиції аріїв: на щляху до реалій українських бойових мистеитв. Тернопіль: Мандрівець.

Мандзяк, О. (2007). Воїнсько-бізичне виховання аріїв: народні ігри в практиці українських бойових мистецтв. Тернопіль: Мандрівець.

Матвеев, О. В. (2002). «Что значит русский бой удальй...?»: ратное ремесло в исторической картине мира Кубанского казачества. W: Семенцов, М. В. (ред.). Дикаревские чтения (8). Итоги фольклорно-этнографических исследований этнических культур Северного Кавказа за 2001 год. Краснодар: Крайбибколлектор.

Медведев, А. Н. (1993). Казаки и рукопашный бой. Москва: Здоровье народа.

Мерлянова, О. А. (2012). Танець у контексті сімейної обрядовості. Українська культура: минуле, сучасне, шляхи розвитку: наукові записки РДГУ. Вип. 18 (1). (Рівне), s. 219-223.

Михайлина, Л. (2007). Слов'яни VIII-X cm. між Дніпром і Карпатами. Київ: Інститут археології НАН України. 
Наумов, С. Н. (2010). Казаки и Казахстан: 400 лет общей судьбы. Алматы: [б. и.].

Новак, В. С. (уклад) (2011). Вясельная традыцыя Гомельшчьны: фальклорна-этнаграбічнь зборнік. (Гомельскі дзяржӑны ўніверсітэт імя Ф. Скарыны). Мінск: Права і эканоміка.

Огієнко, І. І. (1965). Дохристиянські вірування украӥнського народу. Видавництво Вінніпег.

Пилат, В. (1999). Бойовий гопак. Львів: Галицька видавнича спілка.

Сенько, I. (2006). Збірник Ходили Опришки. Online: http://carpathians.eu/?id=733 (15.08.2018).

Снегирев, И. М. (1837). Русские простонародные праздники и суеверные обряды. Москва: Университетская типография.

Терещенко, А. (1848). Быт русского народа. Ч. 4: Забавы. Санкт-Петербург: типография Министерства внутренних дел.

Туманов, А. А. и др. (1999). Русский рукопашный бой. Челябинск: Урал.

Шевцов, А. (2010). Русский бой на любки. Санкт-Петербург: ИГ «Весь».

Устав строевой казачвей службы, (1899). Ч. 1. Санкт-Петербург: В. Березовский. Online: www. scarb.ru/literatura/metodicheskaja/ustav-stroevoj-kazachej-sluzhby/ (13.08.2018).

Щербина, Ф. А. (b.r.w.). Пережитое, передуманное и осуществленное. Подготовил А. Дейневич по материалам Государственного архива Краснодарского края. Online: www.novaderev.ru/ article/sch_b_0.html (13.08.2018).

Яровой, А. В. (2014). Воинская культура казачества: символическое пространство и ритуал. Москва; Берлин: Директ-Медиа. 